\title{
Coping with death and awareness of mortality in patients and their relatives
}

\author{
Vladimir Littva ${ }^{1, *}$ and Anna Kralova ${ }^{2}$ \\ ${ }^{1}$ Catholic University in Ružomberok, Ružomberok, Slovakia \\ ${ }^{2}$ Central Military Hospital -Faculty Hospital, Ružomberok, Slovakia
}

\begin{abstract}
The aim of our study was to analyze the attitudes of people patients and their relatives in proximity of death and dying. End-stage of human life is often associated with changes in the scale of values and needs of the individual. Particular attention was paid to the needs and values that are associated with recognition of limitations concerning to earthly life, but also with the hope of eternal life. Generally, people think that the feelings and coping with death and dying are same in patients and their relatives. The truth is that coping with death and mortality is individual to each person. The problems related to the dying should be coped with by all: dying patients, their relatives and friends. Dying is not letting cold those who are in the presence of dying. In our study we used Acceptation of Dying and Coping with Mortality Questionnaire - 20 Items (ADCMQ20). Research sample consisted of 275 respondents: 95 dying patients and 180 their relatives. All data were processed by SPSS 24 statistical program.
\end{abstract}

Key words: coping, death, dying patient, awareness of mortality, relatives, proximity of death.

\section{Introduction}

End-stage of human life is often associated with changes in the scale of values and needs of the individual. People often begin to realize the transience of life and think about the meaning of dying when someone from their loved ones is in danger of death. They start to think about the problems that have not been resolved and can affect the inner balance and suffering of the patient. Such situation can actually or potentially impair the faith, the system of values which provide the strength, hope and meaning of life. According to O'Brien spiritual distress has the following symptoms:

- Spiritual pain - problems in reconciliation with the loss of a loved one, or great suffering, too big attachment to someone or to something.

- Spiritual alienation - separation from the religious community, separation from the family and loved ones.

- Spiritual anguish - the doubts of opinion or value system, everything is changed, uncertainty.

- Spiritual guilt - failure in faithfulness to religious rules, because of lack of strength or because of weak will.

- Spiritual anger - difficulty accepting the disease or suffering, looking for reason and origin of pain and sufferings.

\footnotetext{
* Corresponding author: vladimir.littva@ku.sk
}

(C) The Authors, published by EDP Sciences. This is an Open Access article distributed under the terms of the Creative Commons Attribution License 4.0 (http://creativecommons.org/licenses/by/4.0/). 
- Spiritual loss - difficulty finding comfort in religion, loss of peace and sulk.

- Spiritual despair - a feeling of lack of interest in his own person, resignation [1].

Respect to the sick forbids us to lie to them. Truth is necessary to tell when there is the best hope that the ill person is able to accept it and process accordingly. What is important is emotional support from relatives. It is important to be true also in our feelings. Dying person has heightened sensitivity and a sharp distinction between reality and hypocrisy. We should give time to patient and freedom to talk about all the things they consider essential. About the topic of approaching end we should not be insistent, but we should wait until they are able to speak alone - it is their decision [2]. The problems related to the dying should be coped with by all: dying patients, their relatives and friends. Dying is not letting cold those who are in the presence of dying. Awareness of one's death leads dying to consider the following areas:

- Recognize their helplessness and weakness. In mismanagement of helplessness, the patient may find themselves in a state of anger at themselves, others, God, the whole world. This leads to resentment, bitterness and rejection. An alternative to this is arousing hope (be careful not false concerning to recovery). We should stress the value of previous part of life, as well as the remaining part of it. For the believer, demonstration of the value of eternity and eternal life is necessary.

- The area of closest relations to relatives and friends. In this area, one is usually trying to quickly take stock and analyze their relations. The proximity of death is changing priorities and point of view for value.

- The area of person's inner life. It is necessary to cope with their conscience, to take stock of their own life and contribution.

These areas often induce stress from the lack of time to implement a possible correction. Within the present situation the loved ones should try to ascertain a dying person about abilities to deal with their past and to highlight the positive aspects of their life either during the lifetime or at the end of it.

Even relatives and friends are in this situation affected by dying of the patient.

- They are aware of their own mortality, especially if they have not yet met directly with the death of the loved ones. The closer they are to the age of dying, the deeper perception of their own mortality are experiencing. People are already dying in our midst, at our age.

- They are aware of the impending loss which will have to be settled in the near future. Their relationships and living conditions will be changed. The closer a person is, the greater are emotional as well as material losses (it is a big difference when the dying is uncle or father).

- They are aware of the need to deal in the personal area with the dying, or other relatives. Outstanding old accounts should be paid, anger is already losing its strength, and it is time for reconciliation.

Patients with an incurable, life-threatening, active, progressive, and life-limiting illness must have all the symptoms that may cause the patient a potential suffering or impairment of the quality of life, including his / her family members [3].

Aim:

The contribution is based on pilot study focused on Acceptance of Dying among Believers and Non-believers Patients and their Environment which is the part of the project KEGA no. 007KU-4/2018. The main tasks of the research are: 
- To identify the impact of variables such as gender, education, age, residence, religion on coping with death and acceptation of mortality.

- Find out who better accepts the proximity of dying: dying patients, or their relatives and acquaintances.

- Find out what is most troubling in the spiritual area in patients and their relatives at the time of death.

- Generally find out the level of coping with dying and mortality in patients and their relatives.

\section{Methods}

\subsection{Study design and setting}

In our survey we used Acceptation of Dying and Coping with Mortality Questionnaire - 20 Items (ADCMQ20) which we analyzed by statistical program SPSS 22 for correlations with $p<0.01$ and $p<0.05$ as well as descriptive characteristic for variables. The questionnaire was constructed by the authors of the paper Vladimír Littva and Anna Králova and subsequently linguistically and psychometrically validated. Questionnaire is divided into two domains:

1. Feelings about death and mortality - 10 questions with possibility of answers: never, rarely, sometimes, often and always. We asked respondents if they felt or if they could cope with some feelings.

2. Perception of own mortality - 10 questions -5 with the same answers as before (using help question: Can You Cope with your own mortality?) and 5 questions with possible answers: strongly disagree, disagree, neither agree and neither disagree, agree, strongly agree. The help question for these five items is: Knowing your own mortality leads you to + item.

Questionnaire evaluation is based on calculation means and correlations between the groups. Research was carried out from November 2017 to February 2018 in Northern Slovakia regions Liptov, Orava and Spiš. To achieve the best return and the most appropriate fulfilment of questionnaire, the collector was always present during the completing of the questionnaire. Survey was conducted with the previously obtained ethical approval

\subsection{Research sample}

Research sample consisted of 275 respondents: 119 (43.3\%) men and 156 (56.7\%) women, $95(34.5 \%)$ dying patients and $180(65.5 \%)$ relatives. Age of all respondents was $18+$. Limitations and decommissioning criteria were based on the following requirements: age between 18 and 80 years and good mental status of the respondent. In the group of dying it was fatal diagnosis with the assumption of death less than one month. In the case of relatives close relationship (siblings, children, parents, husband and wife). We initially approached 340 respondents, but on the basis of the criteria we excluded 25 of them. 40 respondents refused to participate in the survey for various reasons. Written consent was obtained from the patients and study participants in time of survey (just before completing the questionnaire).

\section{Results}

To assess the relevance of each question, a 4-point scale was used based on the criteria proposed by Davis LL. Instrument review [4]. Scale content validity index was 0.96 and 
Table 1. Frequency statistic - respondents.

\begin{tabular}{|c|c|c|c|c|c|c|c|}
\hline & Gender & Age & Education & Religion & Residency & Position \\
\hline \multirow[t]{2}{*}{$\mathrm{N}$} & Valid & 275 & 275 & 275 & 275 & 275 & 275 \\
\hline & Missing & 0 & 0 & 0 & 0 & 0 & 0 \\
\hline \multicolumn{2}{|c|}{ Mean } & 1.57 & 2.28 & 2.28 & 1.71 & 2.33 & 1.65 \\
\hline \multicolumn{2}{|c|}{ Median } & 2.00 & 2.00 & 2.00 & 2.00 & 2.00 & 2.00 \\
\hline \multicolumn{2}{|c|}{ Std. Deviation } & .496 & .737 & .667 & .748 & 1.065 & .476 \\
\hline \multicolumn{2}{|c|}{ Variance } & .246 & .544 & .445 & .559 & 1.133 & .227 \\
\hline \multicolumn{2}{|c|}{ Minimum } & 1 & 1 & 1 & 1 & 1 & 1 \\
\hline \multicolumn{2}{|c|}{ Maximum } & 2 & 3 & 4 & 3 & 4 & 2 \\
\hline
\end{tabular}

Table 2. Reliability of questionnaire.

\begin{tabular}{|l|c|c|}
\hline & Cronbach's Alpha & N of Items \\
\hline Overall Reliability statistics & .885 & 20 \\
\hline Domain 1 Reliability Statistics & .834 & 10 \\
\hline Domain 2 Reliability Statistics & .777 & 10 \\
\hline
\end{tabular}

Total agreement was 0.8. We evaluated the intrinsic reliability of ADCMQ20 using the Cronbach Alpha coefficient which is 0.885 in the whole set. For the domain 1 it was 0.834 and for domain 2 it was 0.777 . The respondents had no problem to understand and fill in questionnaire. These outcomes are telling that questionnaire has strong validity, reliability and consistency.

The task to determine generally the level of coping with dying and mortality was accomplished by using descriptive statistic. Mean for whole set (both domains) was 3.51 but for individual items ranged from 2.90 to 4.01 which represents pretty good coping (maximum was 5.0). Domain 1 focused on Feelings about death and mortality achieved mean 3.57. This suggests that respondents know well how to cope with their feelings in time of dying. The weakest are in area of peace and confidence, and strongest in dejection and life fulfilment. The feeling of peace and hope is associated with something that has not yet been personally experienced and with expectation, while the feeling of dejection and fulfilment of life with something they know and manage themselves. Domain 2 focused on Perception of own mortality achieved mean 3.45. Coping with one's own mortality is not easy as represented by the results of the answers to questions 11, 12 and 13. But we can see that awareness of mortality make people not only think about death, but rather act in better way in their life as is shown in responses to questions 16, 17 and 18. These results are responding the task what is most troubling in the spiritual area in patients and their relatives at the time of death. The people in Slovakia are not anymore so strongly attached to the religion as two decades ago. They are losing the attachment to afterlife as is possible to see in item 20. For more details see Table 3.

In Domain 1 concerning feelings about death and mortality statistically significant difference was confirmed between groups regarding position in 8 items from 10 -dying patients can manage their feelings much better then relatives exception dejection and confidence; regarding residency in 8 items from 10 - people living in countryside are better coping with feelings, even though during the funerals are more explicit; and regarding religion in 9 items from 10 - believing people are accepting death and mortality more serenely than unbelieving. More detailed results are in table 4 . Kober in his research concerning the 
Table 3. Descriptive statistics - answers for items.

\begin{tabular}{|l|c|c|c|c|c|c|}
\hline & Range & Min. & Max. & Mean & Std. Deviation & Variance \\
\hline 01 Satisfaction (Are You Feeling?) & 3 & 2 & 5 & 3.81 & .809 & .655 \\
\hline 02 Dejection (Can You Cope?) & 3 & 2 & 5 & 3.89 & .772 & .597 \\
\hline 03 Tranquillity (Are You Feeling?) & 4 & 1 & 5 & 3.49 & .987 & .973 \\
\hline 04 Confidence (Are You Feeling?) & 4 & 1 & 5 & 3.35 & 1.054 & 1.110 \\
\hline 05 Hope (Are You Feeling?) & 4 & 1 & 5 & 3.46 & .940 & .884 \\
\hline 06 Life fulfilment (Are You Feeling?) & 4 & 1 & 5 & 3.82 & .793 & .629 \\
\hline 07 Confusion (Can You Cope?) & 4 & 1 & 5 & 3.51 & .906 & .820 \\
\hline 08 Inner Power (Are You Feeling?) & 4 & 1 & 5 & 3.55 & .908 & .825 \\
\hline 09 Consolation (Are You Feeling?) & 4 & 1 & 5 & 3.51 & .902 & .813 \\
\hline 10 Peace (Are You Feeling?) & 4 & 1 & 5 & 3.34 & .928 & .861 \\
\hline $\begin{array}{l}\text { 11 Death Generally (Can You Cope with } \\
\text { own mortality?) }\end{array}$ & 4 & 1 & 5 & 3.40 & .880 & .774 \\
\hline $\begin{array}{l}\text { 12 In Own Health Problems (Can You } \\
\text { Cope with own mortality?) }\end{array}$ & 4 & 1 & 5 & 3.40 & .947 & .897 \\
\hline $\begin{array}{l}\text { 13 In Others Health Problems (Can You } \\
\text { Cope with own mortality?) }\end{array}$ & 4 & 1 & 5 & 3.13 & .850 & .723 \\
\hline $\begin{array}{l}\text { 14 In Time of Others Death (Can You } \\
\text { Cope with own mortality?) }\end{array}$ & 4 & 1 & 5 & 3.41 & .756 & .571 \\
\hline $\begin{array}{l}\text { 15 In time of danger (Can You Cope with } \\
\text { own mortality?) }\end{array}$ & 4 & 1 & 5 & 3.40 & .959 & .920 \\
\hline $\begin{array}{l}\text { 16. Try to Become Better (Knowing your } \\
\text { own mortality leads you to) }\end{array}$ & 4 & 1 & 5 & 4.01 & .828 & .686 \\
\hline $\begin{array}{l}\text { 17. Presence of Loved Ones (Knowing } \\
\text { your own mortality leads you to) }\end{array}$ & 4 & 1 & 5 & 3.92 & 1.034 & 1.070 \\
\hline $\begin{array}{l}\text { 18. Reconciliation (Knowing your own } \\
\text { mortality leads you to) }\end{array}$ & 4 & 1 & 5 & 3.56 & 1.404 & 1.970 \\
\hline $\begin{array}{l}\text { 19. Transient Life (Knowing your own } \\
\text { mortality leads you to believe in) }\end{array}$ & 4 & 1 & 5 & 3.41 & 1.141 & 1.302 \\
\hline $\begin{array}{l}\text { 20. Live for Ever (Knowing your own } \\
\text { mortality leads you to believe in) }\end{array}$ & 4 & 1 & 5 & 2.90 & 1.103 & 1.216 \\
\hline Valid N & & & 275 & & \\
\hline
\end{tabular}

*Correlation is significant at the level $p<0.05$

** Correlation is significant at the level $p<0.01$

spiritual needs at the end of life stated that they may not always be associated with life satisfaction, but sometimes with anxiety, and can be interpreted as a patient's desire for spiritual well-being. The need for peace, health and well-being is universal human needs and is particularly important for patients with long-term illnesses [5]. We in our research confirmed contrary also the importance of satisfaction and life fulfilment.

In Domain 2 focused on perception of own mortality statistically significant difference was confirmed between groups regarding position (dying or relatives) in 6 items from $10-$ dying people are cooping better with their mortality as their relatives, but also have stronger attachment to the afterlife. There is not a significant difference regarding the desire to become better, to be with loved ones and to be reconciled, because these feelings and needs are 
Table 4. Correlations statistic - Domain 1.

\begin{tabular}{|c|c|c|c|c|c|c|c|}
\hline & & Gender & Age & Education & Religion & Residency & Position \\
\hline \multirow{2}{*}{01 Satisfaction } & Pearson & $.145^{*}$ & -.079 & .003 & $-.290^{* *}$ & $-.192^{* *}$ & $-.195^{* *}$ \\
\hline & $\begin{array}{l}\text { Sig. } \\
\text { (2-tailed) }\end{array}$ & .016 & .192 & .959 & .000 & .001 & .001 \\
\hline \multirow[t]{2}{*}{02 Dejection } & $\begin{array}{l}\text { Pearson } \\
\text { Correlation }\end{array}$ & $.263^{* *}$ & .004 & -.044 & .043 & $-.248^{* *}$ & .112 \\
\hline & $\begin{array}{l}\text { Sig. } \\
\text { (2-tailed) }\end{array}$ & .000 & .952 & .468 & .473 & .000 & .064 \\
\hline \multirow[t]{2}{*}{03 Tranquillity } & $\begin{array}{l}\text { Pearson } \\
\text { Correlation }\end{array}$ & $.201^{* *}$ & -.015 & -.006 & $-.275^{* *}$ & $-.173^{* *}$ & $-.176^{* *}$ \\
\hline & $\begin{array}{l}\text { Sig. } \\
\text { (2-tailed) }\end{array}$ & .001 & .802 & .927 & .000 & .004 & .003 \\
\hline \multirow[t]{2}{*}{04 Confidence } & Pearson & $.196^{* *}$ & -.062 & -.015 & $-.287^{* *}$ & $-.196^{* *}$ & -.110 \\
\hline & $\begin{array}{l}\text { Sig. } \\
\text { (2-tailed) }\end{array}$ & .001 & .304 & .801 & .000 & .001 & .068 \\
\hline \multirow[t]{2}{*}{05 Hope } & Pearson & $.121^{*}$ & .022 & .066 & $-.316^{* *}$ & $-.183^{* *}$ & $-.126^{*}$ \\
\hline & $\begin{array}{l}\text { Sig. } \\
\text { (2-tailed) }\end{array}$ & .044 & .717 & .279 & .000 & .002 & .037 \\
\hline \multirow[t]{2}{*}{06 Life fulfilment } & $\begin{array}{l}\text { Pearson } \\
\text { Correlation }\end{array}$ & $.221^{* *}$ & -.028 & -.015 & $-.249^{* *}$ & $-.190^{* *}$ & $-.125^{*}$ \\
\hline & $\begin{array}{l}\text { Sig. } \\
\text { (2-tailed) }\end{array}$ & .000 & .646 & .811 & .000 & .002 & .038 \\
\hline \multirow[t]{2}{*}{07 Confusion } & Pearson & $.265^{* *}$ & -.080 & -.065 & $.147^{*}$ & -.003 & $.206^{* *}$ \\
\hline & $\begin{array}{l}\text { Sig. } \\
\text { (2-tailed) }\end{array}$ & .000 & .184 & .285 & .015 & .959 & .001 \\
\hline \multirow[t]{2}{*}{08 Inner Power } & $\begin{array}{l}\text { Pearson } \\
\text { Correlation }\end{array}$ & -.002 & $.120^{*}$ & -.055 & $-.372^{* *}$ & -.067 & $-.257^{* *}$ \\
\hline & $\begin{array}{l}\text { Sig. } \\
\text { (2-tailed) }\end{array}$ & .976 & .047 & .364 & .000 & .268 & .000 \\
\hline \multirow[t]{2}{*}{09 Consolation } & $\begin{array}{l}\text { Pearson } \\
\text { Correlation }\end{array}$ & -.020 & .035 & .069 & $-.405^{* *}$ & $-.201^{* *}$ & $-.124^{*}$ \\
\hline & $\begin{array}{l}\text { Sig. } \\
\text { (2-tailed) }\end{array}$ & .745 & .567 & .257 & .000 & .001 & .039 \\
\hline \multirow[t]{2}{*}{10 Peace } & $\begin{array}{l}\text { Pearson } \\
\text { Correlation }\end{array}$ & .116 & .021 & .096 & $-.323^{* *}$ & $-.232^{* *}$ & $-.169^{* *}$ \\
\hline & $\begin{array}{l}\text { Sig. } \\
\text { (2-tailed) }\end{array}$ & .054 & .723 & .111 & .000 & .000 & .005 \\
\hline $\mathrm{N}$ & \multicolumn{7}{|c|}{275} \\
\hline
\end{tabular}

* Correlation is significant at the level $p<0,05$

** Correlation is significant at the level $p<0,01$ 
Table 5. Correlations statistic - Domain 2.

\begin{tabular}{|c|c|c|c|c|c|c|c|}
\hline & & Gender & Age & Education & Religion & Residency & Position \\
\hline \multirow[t]{2}{*}{11 Death Generally } & \multirow{2}{*}{$\begin{array}{l}\text { Pearson } \\
\text { Correlation } \\
\text { Sig. (2-tailed) }\end{array}$} & .105 & .054 & .030 & $-.270^{* *}$ & $-.308^{* *}$ & $-.226^{* *}$ \\
\hline & & .081 & .372 & .622 & .000 & .000 & .000 \\
\hline \multirow[t]{2}{*}{12 In Own Health Problems } & \multirow{2}{*}{$\begin{array}{l}\text { Pearson } \\
\text { Correlation } \\
\text { Sig. (2-tailed) }\end{array}$} & $.281^{* *}$ & -.022 & -.017 & $-.149^{*}$ & -.071 & $-.334^{* *}$ \\
\hline & & .000 & .722 & .781 & .013 & .239 & .000 \\
\hline \multirow{3}{*}{$\begin{array}{l}13 \text { In Others Health } \\
\text { Problems }\end{array}$} & \multirow{3}{*}{$\begin{array}{l}\text { Pearson } \\
\text { Correlation } \\
\text { Sig. (2-tailed) }\end{array}$} & $.147^{*}$ & .028 & -.022 & -.052 & -.017 & $-.308^{* *}$ \\
\hline & & & & & & & \\
\hline & & .015 & .646 & .710 & .388 & .784 & .000 \\
\hline \multirow[t]{2}{*}{14 In Time of Others Death } & \multirow{2}{*}{$\begin{array}{l}\text { Pearson } \\
\text { Correlation } \\
\text { Sig. (2-tailed) }\end{array}$} & $.135^{*}$ & .064 & -.015 & -.114 & $-.240^{* *}$ & $-.253^{* *}$ \\
\hline & & .025 & .290 & .806 & .058 & .000 & .000 \\
\hline \multirow{3}{*}{15 In time of danger } & \multirow{3}{*}{$\begin{array}{l}\text { Pearson } \\
\text { Correlation } \\
\text { Sig. (2-tailed) }\end{array}$} & -064 & $127 *$ & -007 & $-258 * *$ & -061 & -024 \\
\hline & & -.064 & $.12 \%$ & -.007 & -.250 & -.001 & -.024 \\
\hline & & .287 & .035 & .910 & .000 & .315 & .692 \\
\hline \multirow[t]{3}{*}{ 16. Try to Become Better } & \multirow{3}{*}{$\begin{array}{l}\text { Pearson } \\
\text { Correlation } \\
\text { Sig. (2-tailed) }\end{array}$} & $.415^{* *}$ & -.066 & -.041 & $-.164^{* *}$ & $-.237^{* *}$ & -.052 \\
\hline & & & & & & & \\
\hline & & .000 & .273 & .503 & .006 & .000 & .391 \\
\hline \multirow[t]{3}{*}{ 17. Presence of Loved Ones } & \multirow{3}{*}{$\begin{array}{l}\text { Pearson } \\
\text { Correlation } \\
\text { Sig. (2-tailed) }\end{array}$} & $.548^{* *}$ & -.041 & -.018 & -.079 & $-.260^{* *}$ & -.007 \\
\hline & & 000 & 495 & 761 & 190 & 000 & 908 \\
\hline & & & & & & & \\
\hline \multirow[t]{2}{*}{ 18. Reconciliation } & \multirow{2}{*}{$\begin{array}{l}\text { Pearson } \\
\text { Correlation } \\
\text { Sig. (2-tailed) }\end{array}$} & $.648^{* *}$ & -.090 & -.073 & $-.256^{* *}$ & $-.260^{* *}$ & -.043 \\
\hline & & .000 & .136 & .229 & .000 & .000 & .482 \\
\hline \multirow[t]{3}{*}{ 19. Transient Life } & \multirow{3}{*}{$\begin{array}{l}\text { Pearson } \\
\text { Correlation } \\
\text { Sig. (2-tailed) }\end{array}$} & $.157^{* *}$ & -.015 & -.011 & -.062 & -.019 & $-.253^{* *}$ \\
\hline & & & & & & & \\
\hline & & .009 & .802 & .853 & .308 & .754 & .000 \\
\hline \multirow[t]{3}{*}{ 20. To Live for Ever } & \multirow{3}{*}{$\begin{array}{l}\text { Pearson } \\
\text { Correlation } \\
\text { Sig. (2-tailed) }\end{array}$} & $.446^{* *}$ & -.086 & -.070 & .110 & -.031 & $.190^{* *}$ \\
\hline & & .000 & 153 & 249 & 070 & 614 & 002 \\
\hline & \multirow{2}{*}{\multicolumn{7}{|c|}{275}} \\
\hline $\mathrm{N}$ & & & & & & & \\
\hline
\end{tabular}

important same for the dying people as for people in their full lives. Presence of relatives and friends in time of dying is in certain regions of Slovakia strongly required. A common tradition that no one should die deserted is strong. On the other hand, it is irreplaceable support for the dying. For this reason, an indispensable role for both the deceased and the relatives has support from spiritual care provider. Authors Johnson, Engelberg, Nielsen et al., in their research focused on association of spiritual care provider's activities with family members'satisfaction with care detected a significant association between the occurrence of discussions of patients' wishes for end-of life care and higher overall assessments experience. It may be the case that, for family members, the opportunity to give voice to the patient's wishes and have this acknowledged by a spiritual care provider ensures some support [6].

There are some potential limitations of the study. First of all, the study was conducted in regions that are strongly religious; even though religious affiliation has fallen from 
approximately 87 percent to 72 over the past two decades. It should be noted, however, that due to the supra-regional character of the healthcare facilities in which we conducted the survey, they are occupied by patients and clients from all regions of Slovakia. Secondly, it should be noted that the proximity of death can affect responses due to emotional involvement. On the other hand, it is emotional living and coping that is our object of investigation. The limitation is that the assessment tool has not been used by other researchers and it is therefore impossible to directly compare the results. I do not see a problem in the future as the evaluation tool is free to use.

\section{Conclusions}

Based on the findings, we can conclude that priority needs in life can be changed, but the final stage of life is dominated by spiritual needs. The importance of spiritual needs is declared by authors Best, Butow and Olver who state that patients require their doctors to reflect on their spiritual needs and facilitate their access to their satisfaction [7]. An important fact is the perception of the quality of dying. These are used factors associated with the staff's perception of high-quality dying and death [8]. Equally, the acceptance and coping with death and mortality in relatives is marked by strength of relationships with the dying person.

\section{References}

[1] M.E. O'Brien,The need for spiritual integrity, in H. Yura, M. Walsh. Human needs and the nursing process, Appleton Century Crofts 2, 82-115 (1982)

[2] P. Dobríková- Porubčanová et al. Nevyliečitel'ne chorí v súčasnosti, SSV, 277 (2005)

[3] M. Šichman, Posudzovanie symptómov v paliatívnej starostlivosti. In: Posudzovanie symptómov a spirituálnych potrieb pacientov v paliatívnej starostlivosti, 116 (Slovak Academic Press, 2015)

[4] L.L. Davis, Appl. Nurs. Res. 5, 194-197 (1992)

[5] L. Kober, Rev. Int. Sci. Hum. Nat. 1, 31-58 (2015)

[6] J.R. Johnson, R.A. Engelberg, E.L. Nielsen et al., Crit. Care Med. 42(9), 1991-2000 (2014)

[7] M. Best, P. Butow, I. Olver, Support Care Cancer 22(5), 1333-1339 (2013)

[8] I. Andrasi, Spiritual needs of dying and emergency health care. SHS Web of Conferences SOCIETY. HEALTH. WELFARE 2016 40, 03001 (2018) 